DOI: $10.5800 /$ GT-2021-12-1-0513

\title{
ISOTOPIC AGE AND PALEOGEODYNAMIC POSITION OF ULTRAPOTASSIC MAGMATISM OF CENTRAL CHUKOTKA
}

\section{S.V. Efremov ${ }^{1 \otimes}$, A.V. Travin $\mathbb{1}^{2}$}

${ }^{1}$ Vinogradov Institute of Geochemistry, Siberian Branch of the Russian Academy of Sciences, 1a Favorsky St, Irkutsk 664033, Russia

${ }^{2}$ Sobolev Institute of Geology and Mineralogy, Siberian Branch of the Russian Academy of Sciences, 3 Academician Koptyug Ave, Novosibirsk 630090, Russia

ABSTRACT. The ${ }^{40} \mathrm{Ar} /{ }^{39} \mathrm{Ar}$ dating of ultrapotassic rocks from Central Chukotka shows that these rocks are Early Cretaceous, and yields a narrow range of age variations (109 to $107 \mathrm{Ma}$ ), which correlates fairly well with the range of age variations of granitoids typical of the study area (117-105 Ma). There are thus grounds to suggest that the ultrapotassic magmas and granitoids resulted from the same geological process that can be identified from the material characteristics of the ultrapotassic magmas.

In the modern concepts of the regional geological development, the formation of the granitoid and ultrapotassic magmas can be related to the continental lithosphere extension due to the collision of Eurasian plate and the Chukotka Arctic Alaska continental block.

Using modern genetic models based on the interpretations of the material characteristics of ultrapotassic magmas, it is possible to limit the number of genetic hypotheses and to relate the continental lithosphere extension to the processes that took place in the upper mantle of the study area.

KEYWORDS: ${ }^{39} \mathrm{Ar} /{ }^{40} \mathrm{Ar}$ age; ultrapotassic rocks; Central Chukotka

FUNDING: The study was carried out under the state assignment of Project IX.129.1.3 (No 0350-2016-0029) and financially suported by the Russian Foundation for Basic Research (project 17-05-00399 a) and the Government of the Irkutsk Region (project 17-45-388083 r_a). The ${ }^{39} \mathrm{Ar} /{ }^{40} \mathrm{Ar}$ dating was carried out under the state assignment of the Institute of Geology and Mineralogy SB RAS.

\section{SHORT COMMUNICATION}

Correspondence: Sergey V. Efremov, esv@igc.irk.ru
Received: June 18, 2019

Revised: September 21, 2020 Accepted: October 14, 2020

FOR CITATION: Efremov S.V., Travin A.V., 2021. Isotopic age and paleogeodynamic position of ultrapotassic magmatism of Central Chukotka. Geodynamics \& Tectonophysics 12 (1), 76-83. doi:10.5800/GT-2021-12-1-0513 


\title{
ИЗОТОПНЫЙ ВОЗРАСТ И ПАЛЕОГЕОДИНАМИЧЕСКАЯ ПОЗИЦИЯ УЛЬТРАКАЛИЕВОГО МАГМАТИЗМА ЦЕНТРАЛЬНОЙ ЧУКОТКИ
}

\author{
С.В. Ефремов ${ }^{1}$, А.В. Травин ${ }^{2}$
}

\author{
${ }^{1}$ Институт геохимии им. А.П. Виноградова СО РАН, 664033 Иркутск, ул. Фаворского, 1а, Россия \\ ${ }^{2}$ Институт геологии и минералогии им. В.С. Соболева СО РАН, 630090 Новосибирск, пр-т Академика Коптюга, \\ 3, Россия
}

АНнотАЦИЯ. Выполненное ${ }^{40} \mathrm{Ar} /{ }^{39} \mathrm{Ar}$ датирование ультракалиевых пород Центральной Чукотки показало, что они имеют раннемеловой возраст при узком интервале его вариаций от 109 до 107 млн лет. Этот интервал довольно хорошо укладывается в пределы колебания возраста гранитоидов региона (117-105 млн лет), что позволяет связать образование производных ультракалиевых магм и гранитоидов с единым геологическим процессом и использовать вещественную характеристику ультракалиевых магм для его идентификации.

Согласно современным представлениям о геологическом развитии региона, образование гранитоидных и ультракалиевых магм может быть связано с процессами растяжения континентальной литосферы, возникшего после завершения коллизии Евразии с континентальным блоком Чукотка - Арктическая Аляска.

Использование современных генетических моделей, основанных на интерпретации особенностей вещественной характеристики ультракалиевых магм, позволяет ограничить число генетических гипотез и связать растяжение континентальной литосферы с процессами, протекавшими в верхней мантии региона.

КЛЮЧЕВЫЕ СЛОВА: ${ }^{39} \mathrm{Ar} /{ }^{40} \mathrm{Ar}$ возраст; ультракалиевые породы; Центральная Чукотка

ФИНАНСИРОВАНИЕ: Исследование проведено в рамках выполнения государственного задания по проекту IX.129.1.3 (№ 0350-2016-0029) при поддержке РФФИ и Правительства Иркутской области, проект № 17-45-388083 p_a, РФФИ, проект № 17-05-00399 а. Работа по ${ }^{39} \mathrm{Ar} /{ }^{40} \mathrm{Ar}$ датированию выполнена в рамках государственного задания ИГМ СО РАН.

\section{1. ВВЕДЕНИЕ}

Ультракалиевый магматизм обычно фиксирует периоды глобальных тектонических перестроек, затрагивающих все оболочки Земли. Теоретически, изучая составы ультракалиевых пород, можно довольно уверенно проводить палеогеодинамические реконструкции и фиксировать процессы, протекавшие как в континентальной коре, так и в мантии Земли.

На Центральной Чукотке проявления ультракалиевого магматизма развиты довольно широко. Они приурочены к временному интервалу, ограниченному коллизией континентального блока Чукотско-Арктическая Аляска с Евразией с одной стороны и заложением Охотско-Чукотского вулканогенного пояса (ОЧВП) с другой. Именно в этот период отмечается наиболее интенсивная перестройка континентальной литосферы региона и активное формирование структур Арктического океана.

Используя данные по геологическому положению, геохимии и изотопии производных ультракалиевых магм, можно решить ряд региональных геологических проблем, в частности оценить возможность участия потоков вещества нижних оболочек Земли в формировании «поверхностных» геологических структур.

Однако, чтобы «связать» то или иное геологическое событие с глубинными перестройками в мантии Земли, необходимо иметь маркеры, фиксирующие «генетический тип» и возраст этих перестроек. Такими маркерами могут быть производные ультракалиевых магм.
С этих позиций ключевое значение для палеогеодинамических реконструкций в регионе имеет возраст ультракалиевого магматизма, что определяет актуальность, цель и задачи представленной работы.

Главной целью представленной работы является получение новой информации об изотопном возрасте магматических пород региона и использование вновь полученных данных для критического обзора существующих геодинамических построений.

\section{2. КРАТКИЙ ГЕОЛОГИЧЕСКИЙ ОЧЕРК}

Согласно современным геологическим представлениям, Чукотка входит в состав микроконтинента Чукотка - Арктическая Аляска, отделившегося от Северной Америки после открытия Арктического бассейна в позднеюрское время и аккретированного к Евразии после закрытия Анюйского океана в конце поздней юры начале раннего мела [Zonenshain et al., 1990; Nokleberg et al., 2001; Amato et al., 2015].

Континентальный блок имеет крупноглыбовое строение [Geology ..., 1973; Geological Map ..., 1987]. Он состоит из нескольких террейнов, разделенных зонами глубинных разломов сквозьлитосферного заложения. Ультракалиевые породы в большинстве своем контролируются этими зонами, косвенно свидетельствуя об участии вещества мантии в их генезисе.

В качестве эталонного для региона нами был рассмотрен ультракалиевый магматизм восточного побережья Чаунской губы (рис.1), контролируемый депрессией / 
рифтогенной структурой, заложенной на границе Раучуанского и Чаунского континентальных блоков.

Ультракалиевые породы в этом регионе слагают дайковые пояса, вулканичекие покровы, небольшие интрузии. По взаимоотношению с позднеорогенным гранитоидным комплексом они условно могут быть разделены на догранитные и постгранитные. Догранитные ультракалиевые породы слагают дайки апофизы, ранние фазы гранитоидных плутонов, покровы вулканитов в экзоконтактовых частях гранитоидных интрузий. Постгранитные ультракалиевые породы слагают субвулканические интрузии, секущие позднеорогенные гранитоиды, которые, в свою очередь, секутся посторогенными гранитоидами.

Тесная пространственная связь ультракалиевого магматизма с позднеорогенным гранитоидным комплексом теоретически позволяет использовать палеогеодинамические построения, основанные на возрасте,

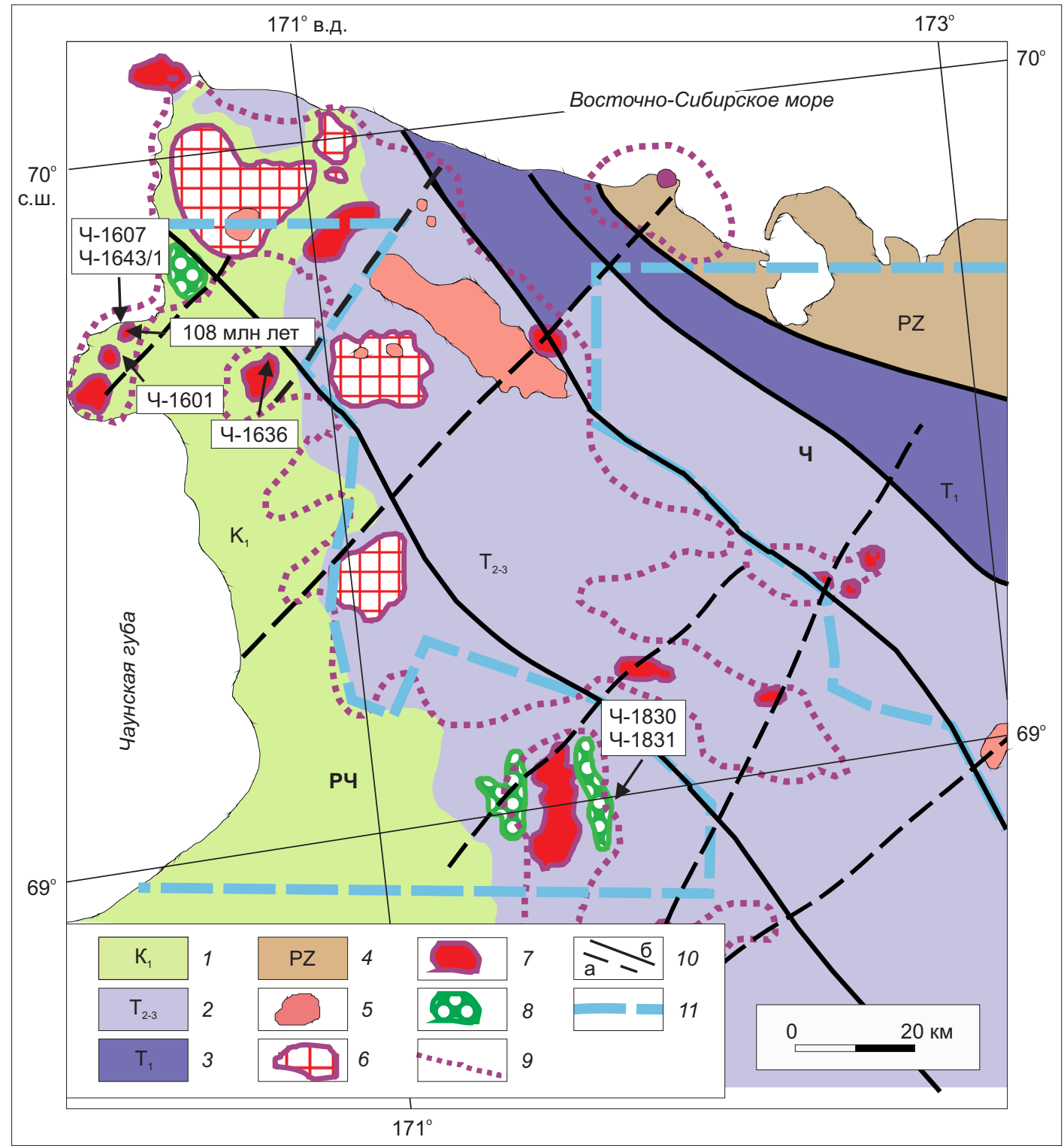

Рис.1. Схематическая геологическая карта восточного побережья Чаунской губы, Чукотка.

1 - раннемеловые вулканогенно-осадочные отложения; 2-3 - флишевые толщи: 2 - среднего - позднего триаса, 3 - раннего триаса; 4 - терригенные и карбонатные породы позднего палеозоя; 5 - посторогенные гранитоиды; 6- 7 - позднеорогенные гранитоиды: 6 - первой фазы, 7 - второй фазы; 8 - ультракалиевые вулканиты; 9 - контуры Восточно-Чаунского батолита; 10 - разломы: а - предполагаемые, б - установленные; 11 - зоны высоких градиентов поля силы тяжести - границы Чаунского (Ч) и Раучуанского (РЧ) континентальных блоков из работы [Begunov et al., 1975].

Fig.1. Schematic geological map of the eastern coast of Chaun Bay, Chukotka.

1 - Early Cretaceous volcanogenic-sedimentary deposits; $2-3$ - flysch strata: 2 - middle - Late Triassic, 3 - Early Triassic; 4 - terrigenous and carbonate rocks of the Late Paleozoic; 5 - post-orogenic granitoids; 6 - 7 - late-orogenic granitoids: 6 - first phase, 7 - second phase; 8 - ultra-potassium volcanites; 9 - contours of the East Chaun batholith; 10 - faults: a - assumed; 6 - established; 11 - zones of high gradients of the gravity field - boundaries of the Chaun (Ч) and Rauchuan (PЧ) continental blocks (after [Begunov et al., 1975]). 
геологическом положении и составе гранитоидов, для выявления процессов, ответственных за образование производных ультракалиевых магм.

\section{1. Возраст и геодинамическая позиция гранитоидного магматизма региона}

По взаимоотношению со складчатыми структурами гранитоиды подразделяются на поздне- и посторогенные [Milov, 1975], а их образование связывается с коллизионным событием, произошедшим в апте - бареме при столкновении микроконтинента Чукотка - Арктическая Аляска с Евразией [Zonenshain et al., 1990; Nokleberg et al., 2001; Amato et al., 2015]. Изотопное датирование современными прецизионными методами $\left({ }^{39} \mathrm{Ar} /{ }^{40} \mathrm{Ar}, \mathrm{U} / \mathrm{Pb}\right.$ по циркону) определило довольно узкий временной интервал проявления гранитоидного магматизма, колеблющийся от 117 до 108 млн лет [Katkov et al., 2010].

Этот магматизм приурочен к этапу регионального растяжения ( 120-105 млн лет), последовавшему после коллизионного сжатия (125-117 млн лет). Формально он должен рассматриваться как постколлизионный. Не исключен вариант связи этого магматизма с рифтогенными процессами, протекавшими в акватории Арктического океана при формировании впадин Подводников и Макарова [Miller, Verzhbitsky, 2009].

Имеющиеся изотопные датировки производных ультракалиевых магм, полученные $\mathrm{Rb} / \mathrm{Sr}$ изохронным методом, колеблются от 113 до 107 млн лет [Efremov et al., 2008], что вполне укладывается в интервал для гранитоидного магматизма. Однако, учитывая то, что $\mathrm{Rb} / \mathrm{Sr}$ изотопная система слабоустойчива к эндогенным и экзогенным преобразованиям, эти возрастные определения должны быть подтверждены другими изотопными методами датирования.

\section{2. ${ }^{39} \mathrm{Ar} /{ }^{40} \mathrm{Ar}$ возраст}

Для изотопного датирования были выделены флогопиты из образцов ультракалиевых пород догранитных и постгранитных субвулканических интрузий, отобранных в пределах и в периферических частях Лоотайпынского (Ч-1636, минетта), Пээкенейского (Ч-1601, керсантит) и Яндрапаакского (Ч-1607, Ч-1643/1, керсантиты) массивов и потоков вулканитов в периферической части Палянского массива (Ч-1830, Ч-1831, мадупиты).

По геолого-структурному положению эти образцы представляют догранитные (Ч-1636), постгранитные дайки (Ч-1601, Ч-1607, Ч-1643/1), сингранитные вулканиты (Ч-1830, Ч-1831). В качестве оценки возраста гранитоидного магматизма была взята датировка 108.1 1.1 млн лет, полученная U/Pb методом по циркону для пород Яндрапаакского массива [Miller, Verzhbitsky, 2009].

Изотопное ${ }^{40} \mathrm{Ar} /{ }^{39} \mathrm{Ar}$ датирование ультракалиевых пород восточного побережья Чаунской губы выполнено методом ступенчатого прогрева с измерением изотопного состава выделенного аргона на масс-спектрометре
Micromass 5400 (Micromass UK Limited). Методика датирования описана в работе Травина и др. [Travin et al., 2009]. Навески минеральных фракций совместно с навесками стандартного образца биотита МСA-11 (OCO № 129-88), используемого в качестве монитора, заворачивались в алюминиевую фольгу, помещались в кварцевые ампулы. Ампулы с образцами запаивались после откачки с прогревом до $200{ }^{\circ} \mathrm{C}$. Биотит МСА-11, подготовленный ВИМС в 1988 г., как стандартный К/Ar образец был аттестован в качестве ${ }^{40} \mathrm{Ar} /{ }^{39} \mathrm{Ar}$ монитора с помощью международных стандартных образцов мусковита Bern 4m, биотита LP-6 [Baksi et al., 1996]. В качестве интегрального возраста биотита МСА-11 принято среднее значение результатов калибровки, составившее 311.0ะ1.5 млн лет. Кварцевые ампулы помещались в алюминиевый пенал, заполненный для защиты от тепловых нейтронов карбидом бора, и облучались в охлаждаемом водой канале научного реактора ВВР-К типа Физико-технического института при Томском политехническом университете. Градиент нейтронного потока не превышал 0.5 \% от размера образца. Эксперимент по ступенчатому прогреву проводился в кварцевом реакторе с печью внешнего прогрева, температура прогрева контролировалась термопреобразователем ТХА/ТХК с точностью $\pm 1^{\circ} \mathrm{C}$. Холостой опыт по ${ }^{40} \mathrm{Ar}$ (10 мин при $\left.1200{ }^{\circ} \mathrm{C}\right)$ не превышал $5 \times 10^{-10}$ нсм $^{3}$. Очистка аргона производилась с помощью ZrAl SAES-геттеров. Изотопный состав аргона измерялся на масс-спектрометре Noble gas 5400 фирмы Микромасс (Англия). Ошибки измерений, приведенные в тексте и на рисунках, соответствуют интервалу $\pm 1 \sigma$. Результаты датирования приведены на рис. 2 и в тексте статьи.

Образец Ч-1636 отобран из дайки лампрофиров в экзоконтакте Лоотайпынского массива (см. рис. 1) и представляет «догранитные» производные ультракалиевых магм. Подвергнут 6-стадийному нагреву от 500

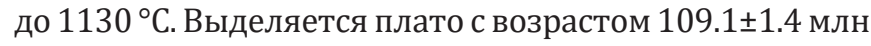
лет, включающее $94 \%$ выделившегося ${ }^{39} \mathrm{Ar}$.

Образец Ч-1601 отобран из дайки экзоконтакта Пээкенейского массива (см. рис. 1). Подвергнут 9-стадийному нагреву от 500 до $1130{ }^{\circ} \mathrm{C}$. Выделяется плато с возрастом 107.6ะ1.3 млн лет, включающее 56 \% выделившегося ${ }^{39} \mathrm{Ar}$.

Образец Ч-1607 отобран из дайки лампрофиров, секущих гранитоиды Яндрапаакского массива, представляет «постгранитные» производные ультракалиевого магматизма региона. Подвергнут 7-стадийному нагреву от 500 до $1130{ }^{\circ} \mathrm{C}$. Выделяется плато возрастом 107.5 \pm 1.3 млн лет, включающее $97 \%$ выделившегося ${ }^{39} \mathrm{Ar}$.

Образец Ч-1643/1 отобран из дайки лампрофира из экзоконтакта Яндрапаакского массива, представляет «постгранитные» производные ультракалиевого магматизма. Подвергнут 9-стадийному нагреву от 500 до

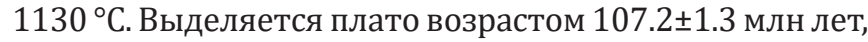
включающее $98 \%$ выделившегося ${ }^{39} \mathrm{Ar}$.

Три последних образца характеризуют время внедрения ультракалиевых магм, секущих позднеорогенные гранитоидные массивы. Все датировки близки 
между собой и полностью перекрываются с изотопным возрастом Яндрапаакского массива, характеризующим позднеорогенные гранитоиды.

Образец Ч-1831 отобран из вулканического покрова в восточном экзоконтакте Палянского массива (см. рис. 1). Он представлен ультракалиевыми флогопитклинопироксеновыми вулканитами - мадупитами. Образец подвергнут 9-ступенчатому нагреву от 500 до $1130{ }^{\circ} \mathrm{C}$. Выделяется хорошее плато с возрастом 108.5 \pm 1.2 млн лет, включающее $95 \%$ выделившегося ${ }^{39} \mathrm{Ar}$.

Образец Ч-1830 отобран из того же вулканического покрова. Он представлен ультракалиевыми флогопит-клинопироксеновыми вулканитами - мадупитами. Подвергнут 6-ступенчатому нагреву от 500 до $1130{ }^{\circ} \mathrm{C}$. Выделяется хорошее плато с возрастом 108.1ะ1.4 млн лет, включающее 98 \% выделившегося ${ }^{39} \mathrm{Ar}$. Оба образца вулканитов имеют близкий изотопный возраст, который, в свою очередь, близок возрасту Яндрапаакского гранитоидного массива.

Новые данные, полученные при изотопном датировании ультракалиевых пород региона, позволяют говорить о том, что проявления ультракалиевого и гранитоидного магматизма в регионе были синхронны по времени и с большой долей вероятности связаны
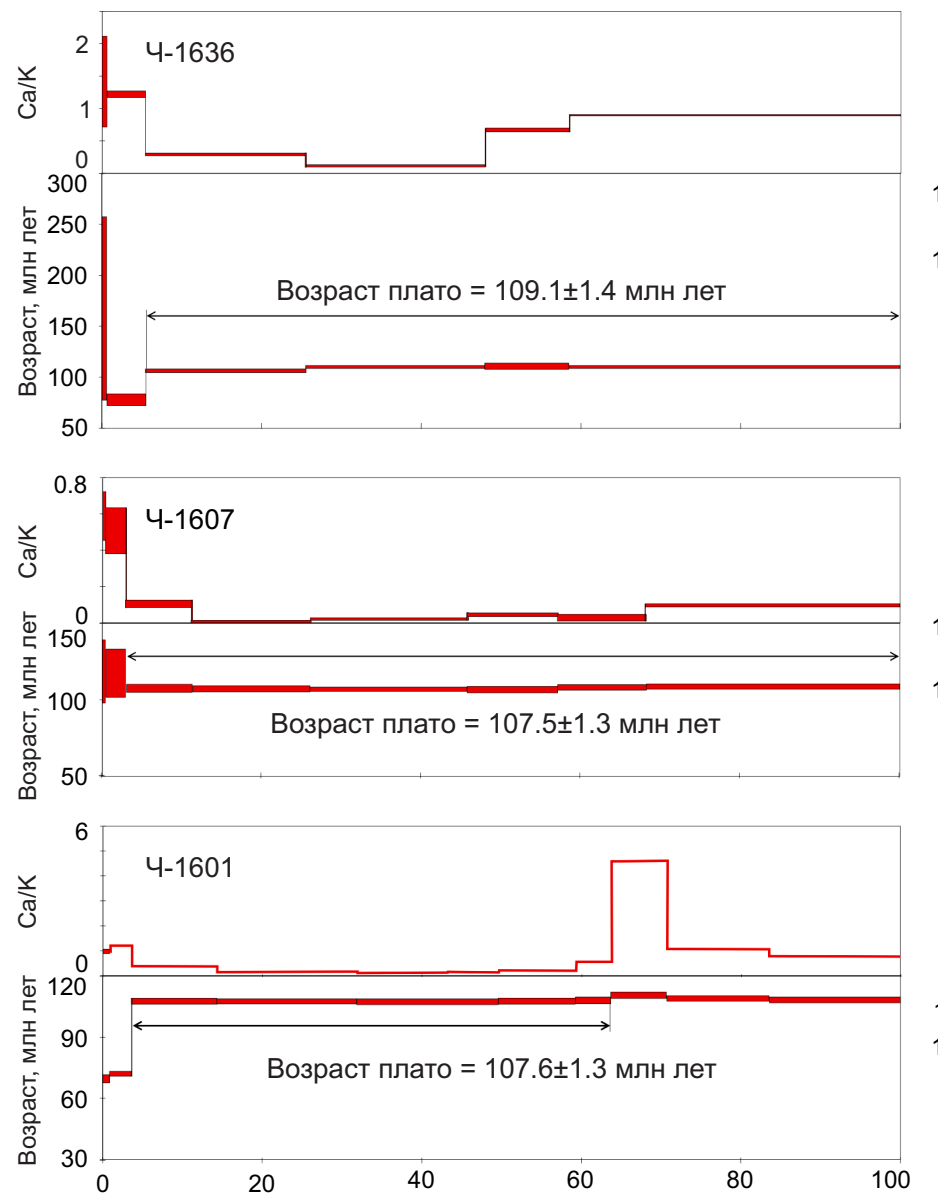

Кумулятивный \% выделенного ${ }^{39} \mathrm{Ar}$ с единым геологическим процессом, вызвавшим глобальную перестройку в пределах континентальной коры и мантии региона.

\section{3. ОБСУЖДЕНИЕ РЕЗУЛЬТАТОВ}

Результаты изотопного датирования, изложенные в предыдущем разделе, позволяют связать ультракалиевый магматизм региона с процессом растяжения континентальной литосферы, возникшего после коллизионного события. Однако, в отличие от гранитоидов, производные ультракалиевых магм позволяют высказать предположение о процессах, вызвавших растяжение континентальной литосферы региона. Обусловлено это тем, что источник ультракалиевых магм расположен в мантии Земли и может быть «ремобилизован» различными процессами, начиная от декомпрессии на границах крупных геологических блоков и заканчивая подъемом горячего вещества (плюмом). Эти процессы, на основании представлений относительно местоположения источника ультракалиевых магм, с той или иной долей вероятности могут быть связаны с глобальными перестройками в пределах различных оболочек Земли, таких как верхняя мантия, нижняя мантия и переходная зона между ними.
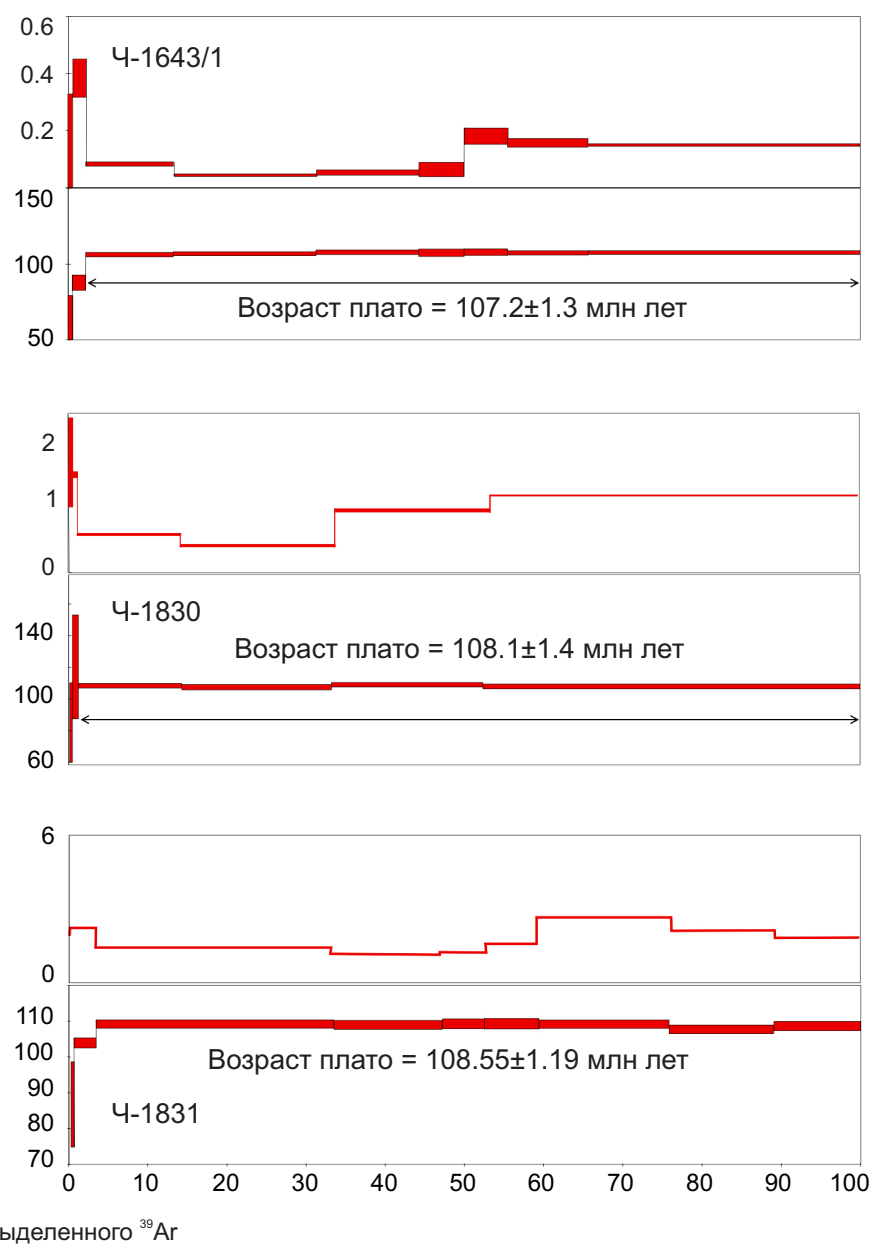

Рис. 2. Спектры ${ }^{39} \mathrm{Ar} /{ }^{40} \mathrm{Ar}$ возраста.

Fig. 2. ${ }^{39} \mathrm{Ar} /{ }^{40} \mathrm{Ar}$ age spectra. 
Для идентификации процессов, ответственных за выплавку ультракалиевых магм, может быть использована их геохимическая и изотопная характеристика.

Производные ультракалиевых магм Центральной Чукотки по своим геохимическим и изотопным характеристикам соответствуют орогенным ${ }^{1}$ [Efremov, Kozlov, 2007; Efremov, 2009, 2012], что довольно хорошо согласуется с их геологическим положением и позволяет предполагать, что их источник находится в пределах субконтинентальной литосферной мантии. Однако положение в субконтинентальной мантии не определяет процесс, приведший к ремобилизации этого источника, ввиду чего необходимо рассмотреть несколько вариантов их образования.

Плюмовая гипотеза. Может быть протестирована по появлению геохимически специализированных пород, таких как карбонатиты, камафугиты, породы, аналогичные по составу базальтам океанических островов (OIB). К настоящему времени в пределах Центральной Чукотки такие породы не обнаружены. Также можно говорить об отсутствии лампроитов, вероятным источником которых является субдуцируемый материал в пределах переходной зоны, а энергетическим источником, способствовавшим выплавлению магм, - плюм [Murphy et al., 2002].

Согласно имеющимся данным [Zhao et al., 2010], на период магмогенерации в переходной зоне под континентальным блоком Чукотка - Арктическая Аляска существовал большой объем субдуцированного вещества, поставляемого плитой Изанаги, плавление которого при прохождении плюма привело бы к образованию лампроитовых магм. В качестве другого свидетельства несостоятельности плюмовой гипотезы может быть использован контур площадного распространения плюма на рис. 8 из работы [Laverov et al., 2013], в пределы которого Центральная Чукотка не входит.

Таким образом, мы довольно уверенно можем исключить плюмовые гипотезы и связать ультракалиевый магматизм Чукотки с процессами, протекавшими в верхней мантии региона в заданный промежуток времени.

Процессы в верхней мантии. Подъем астеносферной линзы и деламинация континентальной литосферы. Эта гипотеза является вариантом плюмовой. Она может быть подтверждена при наличии больших объемов производных магм толеитовых базальтов с геохимической характеристикой N-MORB, E-MORB. Производные магм толеитовых базальтов встречаются в пределах дайковых поясов, сложенных продуктами ультракалиевого магматизма, однако они развиты крайне ограниченно, что свидетельствует о недостаточных объемах плавления для реализации этого механизма.

Ремобилизация источника при коллизии океаническая литосфера - континентальный блок при заложении окраинно-континентальных вулканических поясов. Механизм этого процесса довольно подробно описан в работе [Mlynarczyk, Williams-Jones, 2005]. Он подразумевает формирование кислых гранитоидных и ультракалиевых базальтоидных магм в тыловой зоне вулканического пояса при воздействии океанической литосферы на континентальную в результате резкого увеличения скорости движения океанической плиты.

Возможность образования ультракалиевых магм Чукотки под воздействием этого механизма вполне вероятна и может быть связана с резким увеличением скорости субдукции плиты Изанаги при заложении ОЧВП 106 млн лет назад [Akinin, Miller, 2011]. Однако этому противоречит возраст вулканизма в тыловой зоне Центрально-Чукотского сектора ОЧВП, ограниченный диапазоном 93-77 млн лет [Tikhomirov et al., 2006], что значительно меньше возраста ультракалиевых пород региона.

Существование верхнемантийной ячейки. Этот механизм подробно изложен в работе [Laverov et al., 2013]. Он подразумевает существование ячейки верхнемантийной конвекции под континентом, связанной с субдукцией Тихоокеанской литосферы под Евразийскую и Северо-Американскую литосферные плиты. В рамках этой модели, конвективная верхнемантийная ячейка, «...нижняя горизонтальная ветвь которой течет под континент вдоль переходной зоны между нижней и верхней мантией, а верхняя формирует возвратный поток вещества под литосферой в сторону Тихоокеанской зоны субдукции...» [Laverov et al., 2013, с. 16], приводит к растяжению континентальной литосферы, рифтогенезу и связанному с ним магматизму.

Согласно процитированной работе, именно действие подобной ячейки после закрытия Южно-Анюйского океана и коллизии континентального блока Чукотка - Арктическая Аляска с Евразией привело к смене напряжений в континентальной литосфере региона и развитию субширотного поля растяжений.

В контекст этой модели довольно хорошо укладываются имеющиеся данные по геолого-структурному положению, вещественной характеристике ультракалиевых пород, их малому объему, отсутствию в регионе одновозрастных проявлений магматизма, фиксирующих связь с процессами, протекающими в нижних оболочках Земли.

В качестве причины, приведшей к плавлению, в этом случае следует рассматривать декомпрессию, произошедшую по границам литосферных блоков при «растяжении» орогена.

Полученные авторами статьи новые данные по возрасту ультракалиевого магматизма Центральной Чукотки, конечно же, не позволяют решить сложнейшие геологические проблемы, связанные с идентификацией процессов, ответственных за тектонические движения

${ }^{1}$ Орогенные ультракалиевые магмы образуются в результате ремобилизации субконтинентального литосферного источника, дополненного рециклированным осадочным веществом [Benito et al., 1999; Conticelli et al., 2004; и мн. др.]. Ремобилизация источника может проходить под воздействием различных процессов, протекающих в верхней мантии Земли. 
в континентальной литосфере региона. Однако они могут значительно ограничить количество геодинамических моделей и геохимических резервуаров, участвующих в этом процессе. Они позволяют предполагать, что образование «рифтогенных» структур на Чукотке, в котловинах Макарова и Подводников, связано с процессами, протекавшими в верхней мантии региона, и не имеет отношения к глубинным перестройкам Земли, включающим нижнюю мантию и ядро.

\section{4. ЗАКЛЮЧЕНИЕ}

Выполненное ${ }^{39} \mathrm{Ar} /{ }^{40} \mathrm{Ar}$ методом изотопное датирование производныхультракалиевых магм Центральной Чукотки показало, что они имеют близкий изотопный возраст, укладывающийся в интервал 109-107 млн лет.

Полученные изотопные датировки довольно хорошо согласуются с представлениями о близком возрасте ультракалиевых пород и гранитоидов и позволяют связать их образование с единым геологическим процессом. Следуя принципу аналогии, образование ультракалиевых пород региона можно связать с процессами растяжения континентальной литосферы, возникшими после завершения коллизии Евразии с микроконтинентом Чукотка - Арктическая Аляска.

Полученные авторами статьи новые данные позволяют связать формирование «рифтогенных» структур в пределах Чукотки, котловинах Макарова и Подводников с процессами, протекавшими в верхней мантии региона. Эти процессы не имеют отношения к геологическим перестройкам в оболочках Земли, затрагивающим нижнюю мантию и ядро.

\section{5. БЛАГОДАРНОСТИ}

Авторы искренне признательны А.С. Борисенко за помощь, оказанную при выполнении научных исследований, результатом которых является эта статья.

\section{6. ЛИТЕРАТУРА/REFERENCES}

Akinin V.V., Miller E.L., 2011. Evolution of Calc-Alkaline Magmatism of the Okhotsk-Chkotka Volcanogenic Belt. Petrology 19 (3), 249-292 (in Russian) [Акинин В.В., Миллер Э.Л. Эволюция известково-щелочного магматизма Охотско-Чукотского вулканогенного пояса // Петрология. 2011. Т. 19. № 3. С. 249-292].

Amato J.M., Toro J., Akinin V.V., Hampton B.A., Salnikov A.S., Tuchkova M.I., 2015. Tectonic Evolution of the Mesozoic South Anyui Suture Zone, Eastern Russia: A Critical Component of Paleogeographic Reconstructions of the Arctic Region. Geosphere 11 (5), 1530-1564. https://doi.org/10.11 30/GES01165.1.

Baksi A.K., Archibald D.A., Farrar E., 1996. Intercalibration of ${ }^{40} \mathrm{Ar} /{ }^{39} \mathrm{Ar}$ Dating Standarts. Chemical Geology 129 (3-4), 307-324. https://doi.org/10.1016/0009-2541(95) 00154-9.

Begunov S.F., Zhuravlev G.F., Larionov Ya.S. et al., 1975. Map of Regularities in the Distribution of Mineral Deposits in the Territory of the Chaun Complex Expedition. East Chukotka Geological Exploration Report. SVGU, Pevek, 288 p. (in
Russian) [Бегунов С.Ф., Журавлев Г.Ф., Ларионов Я.С. и др. Карта закономерностей размещения месторождений полезных ископаемых на территории деятельности Чаунской комплексной экспедиции: Отчет ВЧГРЭ. Певек: СВГУ, 1975. 288 с.].

Benito R., Lopez-Ruiz J., Cebria J.M., Hertogen J., Doblas M., Oyarzun R., Demaiffe D., 1999. Sr and O Isotope Constrains on Source and Crustal Contamination in the High-K CalcAlcaline and Shoshonitic Neogene Volcanic Rocks of SE Spain. Lithos 46 (4), 773-802. https://doi.org/10.1016/S00244937(99)00003-1.

Conticelli S., Melluso L., Perini G., Avanzinelli R., Boari E., 2004. Petrologic, Geochemical and Isotopic Characteristics of Potassic and Ultrapotassic Magmatism in Central-Southern Italy: Inferences on Its Genesis and on the Nature of Mantle Sources. Periodico di Mineralogia 73 (1), 135-164.

Efremov S.V., 2009. Geochemistry and Genesis of Ultrapotassic and Potassic Magmatic Rocks on the Eastern Shore of Chaun Bay in Chukotka and Their Role in the Metallogenic Specialization of Tin-Bearing Granitoids. Russian Journal of Pacific Geology 3, 80-90. https://doi.org/10.1134/S18 19714009010084.

Efremov S.V., 2012. Rare Metal Granitoids of Chukotka. Geochemistry, Sources, and Models of Formation. Brief PhD Thesis (Doctor of Geology and Mineralogy). Irkutsk, 21p. (in Russian) [Ефремов C.В. Редкометалльные гранитоиды Чукотки. Геохимия, источники вещества, модели образования: Автореф. дис. ... докт. геол.-мин. наук. Иркутск, 2012. 21 c.].

Efremov S.V., Kozlov V.D., 2007. Ultrapotassic Basites in the Central Chukchi Region and Their Role in Genesis of SNBearing Granites. Russian Geology and Geophysics 48 (2), 221-223. https://doi.org/10.1016/j.rgg.2007.02.006.

Efremov S.V., Kozlov V.D., Sandimirova G.P., Dril' S.I., 2008. Isotope Dating of Ultrapotassic Magmatism in the Central Chukchi Region: Rb/Sr Age and Geochemistry of Monzonites of the Linkor Stock. Russian Geology and Geophysics 49 (4), 240-244 (in Russian) [Ефремов С.В., Козлов В.Д., Сандимирова Г.П., Дриль С.И. Изотопное датирование ультракалиевого магматизма центральной Чукотки. $\mathrm{Rb} / \mathrm{Sr}$ возраст и геохимические особенности монцонитов штока Линкор // Геология и геофизика. 2008. Т. 49. № 4. C. 240-244].

Geological Map of the Magadan Region and Adjacent Territories, 1987. Scale 1: 2500000. SVPGO, Magadan (in Russian) [Геологическая карта Магаданской области и сопредельных территорий. Масштаб 1:2500000. Магадан: ГКП СВПГО, 1987].

Geology of Northeast Asia, 1973. Nedra, Leningrad, 280 p. (in Russian) [Геология Северо-Восточной Азии. Л.: Недра, 1973. 280 с.].

Katkov S.M., Miller E.L., Toro J., 2010. Structural Paragenesis and Age of Deformation of the Western Sector of the Anyui-Chukotka Fold System. Geotectonics 5, 60-80 (in Russian] [Катков С.М., Миллер Э.Л., Торо Дж. Структурные парагенезы и возраст деформаций западного сектора Анюйско-Чукотской складчатой системы // Геотектоника. 2010. № 5. С. 60-80]. 
Laverov N.P., Lobkovsky L.I., Kononov M.V., Dobretsov N.L., Vernikovsky V.A., Sokolov S.D., Shipilov E.V., 2013. Geodynamic Model of the Development of the Arctic Basin and Adjacent Territories for the Mesozoic and Cenozoic and the Outer Boundary of the Continental Shelf of Russia. Geotectonics 1, 3-35 (in Russian) [Лаверов Н.П., Лобковский Л.И., Кононов М.В., Добрецов Н.Л., Верниковский В.А., Соколов С.Д., Шипилов Э.В. Геодинамическая модель развития Арктического бассейна и примыкающих территорий для мезозоя и кайнозоя и внешняя граница континентального шельфа России // Геотектоника. 2013. № 1. C. 3-35].

Miller E.L., Verzhbitsky V.E., 2009. Structural Studies near Pevek, Russia: Implications for Formation of the East Siberian Shelf and Makarov Basin of the Arctic Ocean. In: D.B. Stone, K. Fujita, P.W. Layer, E.L. Miller, A.V. Prokopiev, J. Toro (Eds), Geology, Geophysics and Tectonics of Northeastern Russia: A Tribute to Leonid Parfenov. European Geosciences Union. Stephan Mueller Publication Series 4, 223-241. https://doi. org/10.5194/smsps-4-223-2009.

Milov A.P., 1975. Late Mesozoic Granitoid Formations of Central Chukotka. Nauka, Moscow, 128 p. (in Russian) [Милов А.П. Позднемезозойские гранитоидные формации Центральной Чукотки. М.: Наука, 1975. 128 с.].

Mlynarczyk M.S.J., Williams-Jones A.E., 2005. The Role of Collisional Tectonics in the Metallogeny of the Central Andean Tin Belt. Earth and Planetary Science Letters 240 (34), 656-667. https://doi.org/10.1016/j.epsl.2005.09.047.

Murphy D.T., Collerson K.D., Kamber B.S., 2002. Lamproites from Gaussberg, Antarctica: Possible Transition Zone Melts of Archaean Subducted Sediments. Journal of
Petrology 43 (6), 981-1001. https://doi.org/10.1093/ petrology/43.6.981.

Nokleberg W.J., Parfenov L.M., Monger J.W., Norton I.O., Khanchuk A.I., Stone D.B., Scotese C.R., Scholl D.W., Fujita K., 2001. Phanerozoic Tectonic Evolution of the Circum-North Pacific. United States Geological Survey 1626, 122 p.

Tikhomirov P.L., Akinin V.V., Ispolatov V.O., Alexander P., Cherepanova I.Yu., Zagoskin V.V., 2006. The Age of the Northern Part of the Okhotsk-Chukotka Volcanogenic Belt: New Data of Ar-Ar and U-Pb Geochronology. Stratigraphy and Geological Correlation 14 (5), 81-95 (in Russian) [Тихомиров П.Л., Акинин В.В., Исполатов В.О., Александер П., Черепанова И.Ю., Загоскин В.В. Возраст северной части ОхотскоЧукотского вулканогенного пояса: Новые данные $\mathrm{Ar}-\mathrm{Ar}$ и U-Pb геохронологии // Стратиграфия. Геологическая корреляция. 2006. Т. 14. № 5. С. 81-95].

Travin A.V., Yudin D.S., Vladimirov A.G., Khromykh S.V., Volkova N.I., Mekhonoshin A.S., Kolotilina T.B., 2009. Thermochronology of the Chernorud Granulite Zone, Ol'khon Region, Western Baikal Area. Geochemistry International 47, 1107-1124. https://doi.org/10.1134/S0016702909 110068.

Zhao D. Pirajno F., Dobretsov N.L., Liu L., 2010. Mantle Structure and Dynamics under East Russia and Adjacent Regions. Russian Geology and Geophysics 51 (9), 925-938. https://doi.org/10.1016/j.rgg.2010.08.003.

Zonenshain L.P., Kuzmin M.I., Natapov L.M., 1990. Tectonics of Lithospheric Plates of the USSR. Book 1. Nedra, Moscow, 328 p. (in Russian) [Зоненшайн Л.П., Кузьмин М.И., Натапов Л.М. Тектоника литосферных плит территории СССР. Кн. 1. М.: Недра, 1990. 328 с.]. 